\title{
Fractured reservoir distribution characterization using folding mechanism analysis and patterns recognition in the Tabnak hydrocarbon reservoir anticline
}

\author{
Hamid Sarkheil ${ }^{1} \cdot$ Hossein Hassani ${ }^{2} \cdot$ Firuz Alinia $^{2}$ \\ Received: 12 February 2021 / Accepted: 22 June 2021 / Published online: 30 June 2021 \\ (c) The Author(s) 2021
}

\begin{abstract}
Naturally, fractured reservoirs play a considerable part in the study, production, and development of hydrocarbon fields because most hydrocarbon reservoirs in the Zagros Basin are naturally fractured. Production from those reservoirs is usually affected by the presence of a system of connected fractures. In this study, the Tabnak hydrocarbon field on the fold-thrust belt at the Zagros zone in the Persian plate has been analyzed by the facies models, folding mechanism analysis to identify fracture reservoir patterns. The results show a flexural fold with similarity in the folding mechanism and some open fracture potential made by limestone, shale, clay, and anhydrite in the study area's facies models. Consequently, the stress pattern and type of fracture issue on the fold's upper and lower layers will be similar. On the Tabnak anticline reservoir using image processing techniques in MATLAB R2019 software and kriging geostatistical methods, fracture surface patterns as a block model extended to the depth. Using the model results, fractures' orientation distribution in adjacent wells 11, 14, and 15 is appropriate. The results also have similarities with the facies models, folding mechanism assessment, well test, and mud loss data analysis. These results can affect the development plans' primary approach by drilling horizontal and sleep wells and hydrocarbon reservoir management strategies.
\end{abstract}

Keywords Fracture $\cdot$ Folding Mechanism $\cdot$ Facies $\cdot$ Tabnak $\cdot$ Geostatistics

\section{Introduction}

The Zagros orogenic belt in Iran is part of the Alpine-Himalayan mountain range, extending about $2000 \mathrm{~km}$ from the northwest (Anatolian Fault in Eastern Turkey) to the southeast Oman Line (Berberian and King 1981; Alavi 1994).

In the folded-thrust Zagros belt, two different types of folds are observed, one of which is bending folds and the other is fault-related folds. Most fault-related folds are composed of different members (Jamison 1987; Wallance and Homza 2004; Suppe et al. 2004; De Vera et al. 2009). Other folding mechanisms, such as salt-affected folds and compact folds, are seen in the Zagros but are not common. In the

Hamid Sarkheil

Sarkheil@khu.ac.ir

1 Faculty Member of Earth Sciences, Kharazmi University, Tehran, Iran

2 Faculty Member of Mining and Metallurgical Engineering, Amirkabir University of Technology, Tehran, Iran
Zagros belt, important parameters include the thickness of calcareous units such as Asmari and Sarvak Formations. In addition, the number of separated zones by replacing evaporitic rocks (anhydrite) and shales creates a volumetric mechanical anisotropy for several bent layers (Sepehr et al. 2006).

On the other hand, there are several separation horizons in the cover rocks of the folded-thrust Zagros belt. However, these horizons are not uniform, and lateral changes in the physical components of the cover rock sequence are not observed in all regions of the Zagros. As a result, different parts of the Zagros belt (Lorestan, Dezful, and Fars region) include different structural styles. Severe anisotropy usually occurs in parts of a fold when the layers are relatively thin and loose, and during the folding process, the layering surfaces show little slip resistance. Furthermore, the lowest mechanical anisotropy occurs when the layers are relatively thick and strong in terms of mechanical strength, and slipping of the layering surfaces does not occur easily. In the central parts of the Zagros, due to the presence of numerous harmonious and cohesive horizons, cover rocks with severe 
mechanical anisotropy are seen (Sepehr et al. 2006). In the study area in Tabnak hydrocarbon anticline due to the homogeneity of the formations that are exposed at the ground with hydrocarbon-producing formations, i.e., Kangan and Dalan, the thickness and strength of the region layers and also the approximate horizontal layer. In the study area, anisotropy can be considered minimal for this area and, consequently, the pattern of fractures due to bending of folds in surface formations can be considered similar to the classes of deeper formations. Folded Belt-Zagros Thrust is separated from the submerged zone of Zagros by folds with double planch and NW-SE extension. The anticlines in this zone are usually symmetrical and inverted and have a style parallel to the fixed layers' thickness and are often formed by flexural-slip folding mechanisms (Everts et al., 1977; Alavi 1994, 2007). Wrinkles are often propagated by faults (Suppe, 1983; Suppe and Medwedeff, 1990) or flexural-fault folds (Suppe, 1983).

Natural fractures are mechanical breaks in rocks, and geological formations as a spatial distribution can be a complex function of different geological factors (Al-Rubaye et al. 2021). They occur at different scales, and ordinary is highly heterogeneous. Rock fracturing is a complicated process, which is sensitive to changes in geological conditions under lithostatic, fluid pressures, tectonic, facies (Eahsanul Haque et al. 2018), thermal, and other geological stresses such as uplifting, volcanoes, folding, and salt intrusion. In general, fractures initiate and propagate when the rock's stresses become equal or greater than the rock's strength (Sarkheil et al. 2013).

Usually, in exploration studies based on structural geology and reservoir fractures, available data are seismic, porosity, permeability, lithology, bed thickness, state of stress, fault patterns, folding patterns, and production data. As a result of its analysis, the outcome is a network map of fracture index/intensity for each discrete block. The approach uses fuzzy logic (Sarkheil et al. 2020) to quantify and rank the importance of each geological parameter on fractures and neural networks to account for complex, nonlinear relationships between these geological parameters and the fractured index (Sarkheil et al. 2013).

Neural networks, which can extract relationships under observed data among several variables, are considered an excellent tool for estimating fracture density as a function of several geological parameters. The neural network is suitable for analyzing the complex nonlinear system because no prior knowledge of the functional structure among variables is required. Quenes et al. (1998) used neural networks to analyze the ultimate distribution of recovery in the fractured natural reservoir as a function of bed thickness, resistance formation, and curvature formation.

It is commonly observed that fractures naturally develop in different sets in orientation, density, and geometrics parameters (Quenes et al. 1998).
Fractal behavior has been observed in natural fracture patterns (Barton and Larson 1985; Sarkheil et al. 2010, 2013). Fractal geometry provides a quantification of size scaling or scale dependency of complex fracture systems. The significant aspect of a multi-fractal analysis is to detect the multiscaling chain. So that, in multi-fractal analysis, the box-counting grid technique has been used to gather information about the distribution of pixel values, which becomes the basis for a series of calculations that reveal and explore the multiple scaling rules of multi-fractals. Magnificent exposures of folds by NW-SE trending dominate structural style and its relationship to the Zagros fold-thrust belt's morphology. These folds differ in their geometry and specifications in this area. One of the fold-thrust belt regions is the Tabnak anticline located in the eastern part of the Asaloyeh hydrocarbon field.

High gas production from some formations of the Tabnak hydrocarbon field in Iran indicates a naturally fractured reservoir dominated by structural fractures and facies models. In contrast, gas flow occurs along with open fractures. (Sarkheil et al. 2009a, b, 2010, and 2013).

In this study, to identify the pattern of natural fractures in Tabnak hydrocarbon reservoir, folding mechanism and facies models are used to investigate the effects of porosity, permeability, fracture density on the part of a back limb of Tabnak fold. And also using image processing techniques in MATLAB R2019 software and kriging geostatistical methods, fracture surface patterns developed to the depth.

\section{Method and/or Theory}

Tabnak hydrocarbon field is located on the Zagros zone's fold-thrust belt in the Persian plate (Fig. 1). The formations homogeneity in the study area, occurrences on the surface, and hydrocarbon production potential (specially Kangan and Dalan formation) are among its characteristic features. The layers' thickness and strength and the layers' approximate horizontality can be minimized for anisotropy. Secondary fractures due to folding depend on the mechanical behavior of the stressed layers and how the stress is distributed between them, so that if the fold is flexural-sliding, the stress distribution pattern and consequently, the type of stress-induced fractures. The incidence on the surface layers of the fold and the lower layers are similar, still, suppose the fold in the area is flexuralshear. In that case, i.e., there is friction between the layers instead of slipping, the pattern of stress distribution on the surface layers of the fold compared to the lower layers (located in depth) is different, so different fractures occur than deep layers in floors. Hence, due to the fold's bending, the fracture pattern in surface formations is similar to the layers of deeper formations (Fig. 2a, b). 


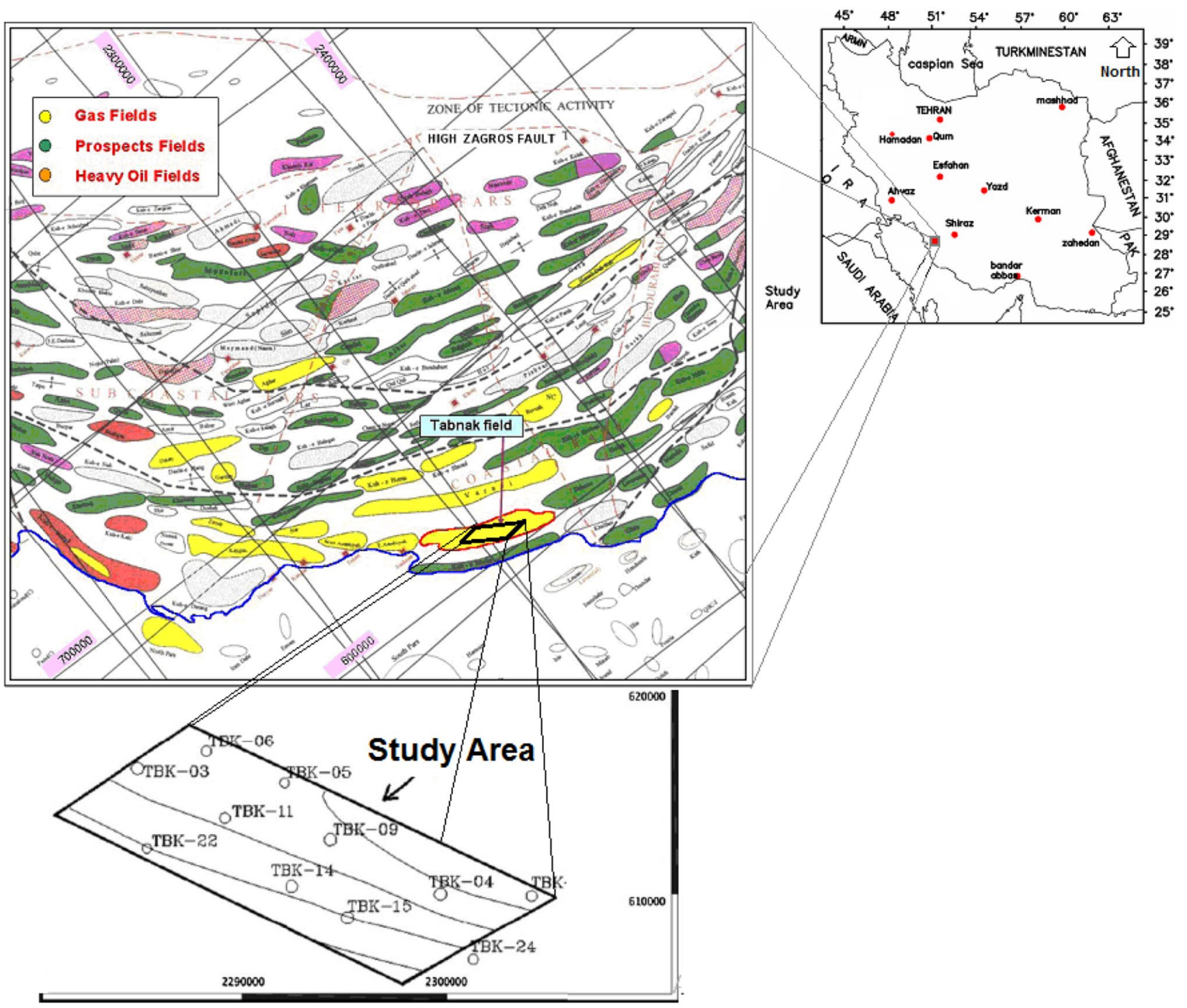

Fig. 1 Tabnak hydrocarbon field on the Zagros zone in the Persian plate and the study area (The original map is adapted from the NIOC)
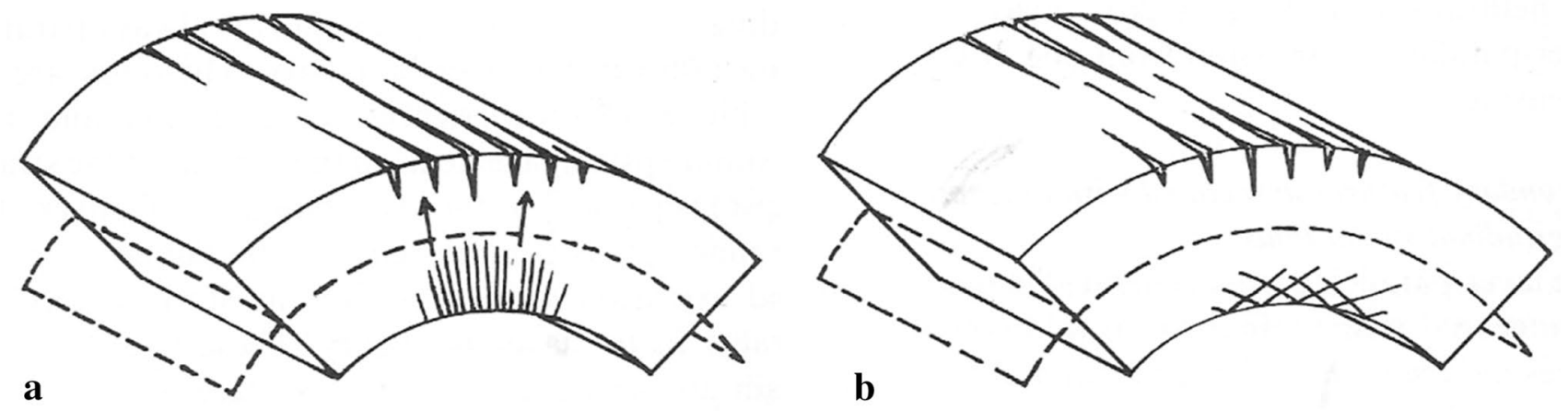

Fig. 2 Secondary fractures resulting from stress distribution patterns due to the mechanical behavior of layers. a Fractures in the upper and lower sections of the floors in a flexural-slipping fold; and $\mathbf{b}$ Fractures in the upper and lower classes in a flexural shear [16]

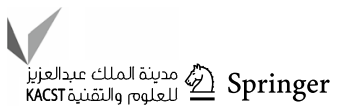


As previously researched, on the mechanism of folding of Zagros, Zagros Fold-Thrust Belt is separated by double folds along the NW-SE from the Zagros Imbricate Zone. Along with usually symmetrical anticlines in this zone, they have a similar style with the thickness of fixed layers and are mostly formed by the flexural-slip folding mechanisms (Alavi 1994 and 2007): Fault-propagation folds (Suppe 1983; Suppe and Medwedeff 1990) or fault-bend folds (Suppe 1983).

Tabnak hydrocarbon anticline can be considered similar to a flexural-slip bending mechanism. By identifying the folding mechanism in the Tabnak anticline, the pattern of stress distribution, and the consequence of fractures resulting from stress on the fold's surface layers, the lower layers can be considered similar. Furthermore, a model can be estimated to generalize the earth's surface fractures to a depth.

In this study, various data that were widely available, reliable, and high quality were used. Of course, it can be mentioned that the scope of the study block on the Tabnak anticline was selected in such a way that it has a variety of data with appropriate quality. The data used in this research are divided into the following groups:

1) Spatial data: These include fracture information from surface surveys performed in the Tabnak anticline range and the use of aerial and satellite imagery.
2) Mud loss data: This group of information has been obtained from the waste reports of the National Iranian Oil Company.

3) Porosity and permeability data: This information results from the analysis of drilling cores in wells in the study area.

4) Data related to shale volume and facies: This information is obtained from petrophysical studies available at the National Iranian Oil Company.

5) Fracture density data related to folding mechanisms: This information has been used by video logs (FMI), in collaboration with Schlumberger Company, and reinterpretation of logs for wells in the study area of Tabnak field to verify the information.

6) Mud Loss Reports

On the Tabnak anticline reservoir using image processing techniques in MATLAB R2019 software and kriging geostatistical methods, fracture surface patterns as a block model extended to the depth. The results are also compared with the facies models, folding mechanism assessment, well test, and mud loss data analysis (Fig. 3).

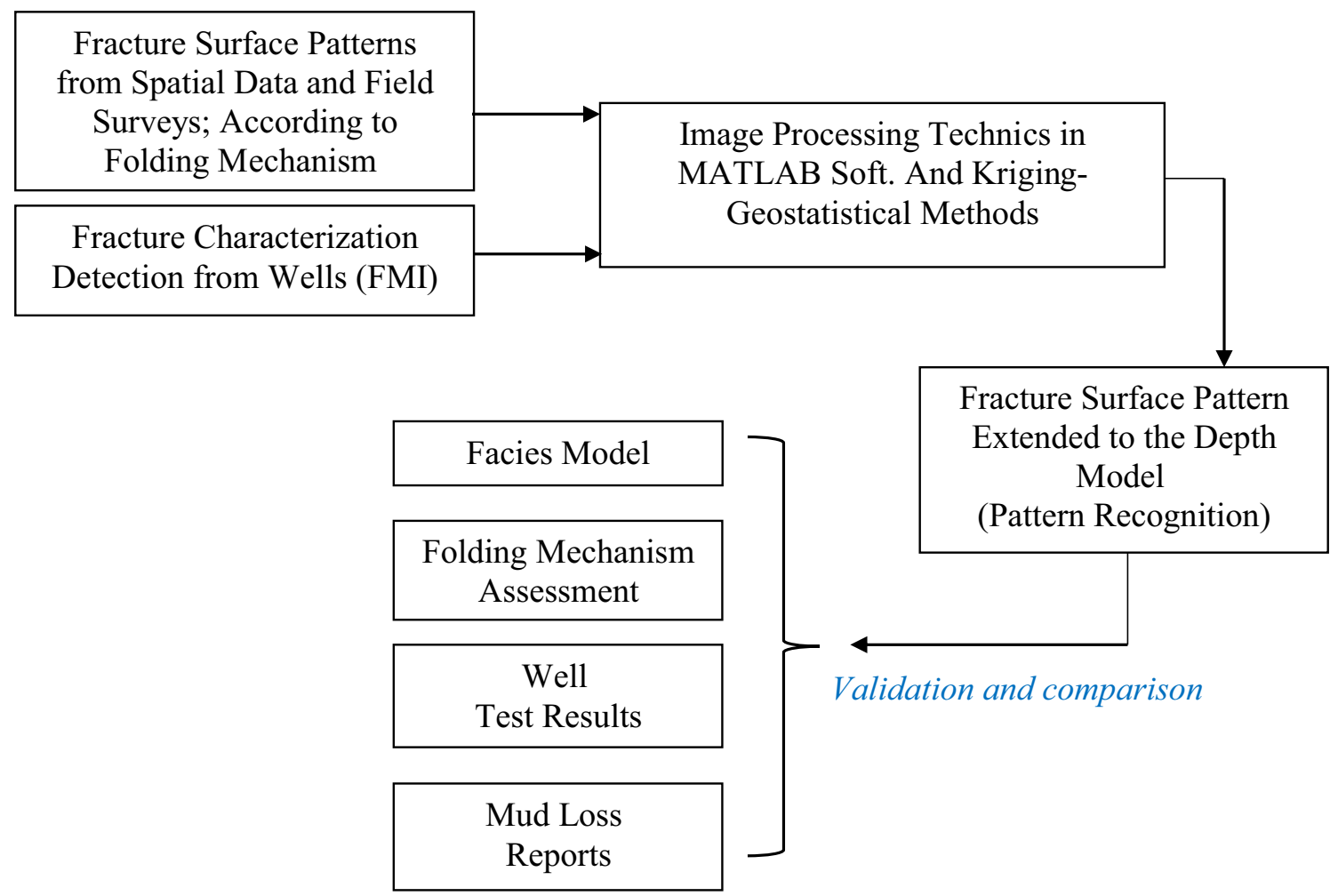

Fig. 3 Flowchart of the present research method 


\section{Result and conclusion}

\section{Facies model}

Since the hydrocarbon reservoir facies information and the shale or clay volume data in the formation, it is essential to analyze the presence or absence of fractures in the formation and the open or closed fractures; litho-facies can be essential in completing the identification of fracture distribution. For this goal, the results of petrophysical data on Tabnak hydrocarbon field wells have been used for facies modeling.

In the next step, a lithology diagram was prepared for each well to make a litho-facies model. Finally, in the study's continuation, petrophysical data (shale, dolomite, limestone, and anhydrite volume) have been used to identify the formations of litho at the desired depth (Fig. 4).

Also, Fig. 1 shows litho-type categories, as follows: dolomitic limestone (6) with calcareous dolomite (5), argillic limestone (7) with argillic dolomite (8), and anhydrite limestone (9) with anhydrite dolomite (10). Finally, seven types of rocks were modeled for facies modeling (Table 1).

Also, another part of the research facies model of the Tabnak hydrocarbon reservoir, Kangan, and Dalan Formations has been studied. The lithology-type petrophysical results were first considered for each interval and numerical value according to Table 1 . In contrast, these were assigned to different two-dimensional facies model formations, and they were plotted for the study area on the Tabnak hydrocarbon reservoir according to Figs. 4 and 5.

Analyzing results show the two-dimensional model in this study area, especially for the Kangan Formation,
Table 1 Types of rocks designated for determination of facies model in Tabnak reservoir

which is considered for a depth of $2350 \mathrm{~m}$. The study area's significant components consist of dolomite, limestone, and anhydrite lithology.

According to Fig. 5, it can be seen in the results of the two-dimensional model for the Kangan Formation, between wells 14 and 15, which are made of limestone and no shale, clay, and anhydrite. So that in the components of this region, there is no filled-fracture material. So, it can be a profitable area for open fractures and consequently, have a high potential for hydrocarbon or water production. It should be noted, however, that this calcareous range does not extend much more in-depth. Whereas in the twodimensional facies model of Fig. 6, which is related to the Dalan Formation is not seen in the range with the possibility of these open fractures between wells 14 and 15 .

The two-dimensional model of Fig. 6 shows the Dalan Formation, which is considered at a depth of $2750 \mathrm{~m}$. The study area's significant components are lithologically composed of dolomite, carbonate anhydrite, and anhydrite.

Facies Modeling Relations

If Dolomite $>=65 \%$ Then Litholog $=1$

If Calcite $>=65 \%$ Then Litholog $=2$

If Clay $>=40 \%$ Then Litholog $=3$

If Anhydrite $>=40 \%$ and Clay $<40 \%$ Then Litholog $=4$

If Dolomite $<65 \%$ and Dolomite $>40 \%$ and Calcite $<40 \%$ and Calcite $>20 \%$ Then Litholog $=5$

If Calcite $<65 \%$ and Calcite $>40 \%$ and Dolomite $<40 \%$ and Dolomite $>20 \%$ Then Litholog $=6$

If Calcite $<80 \%$ and Calcite $>40 \%$ and Clay $<40 \%$ and Clay $>15 \%$ Then Litholog $=7$

If Dolomite $<80 \%$ and Dolomite $>40 \%$ and Clay $<40 \%$ and Clay $>15 \%$ Then Litholog $=8$

If Calcite $<80 \%$ and Calcite $>40 \%$ and Anhydrite $<40 \%$ and Anhydrite $>10 \%$ Then Litholog $=9$

If Dolomite $<80 \%$ and Dolomite $>40 \%$ and Anhydrite $<40 \%$ and Anhydrite $>10 \%$ Then Litholog $=10$

Fig. 4 Conditional relationships applied to the determination of facies model in Tabnak hydrocarbon reservoir 


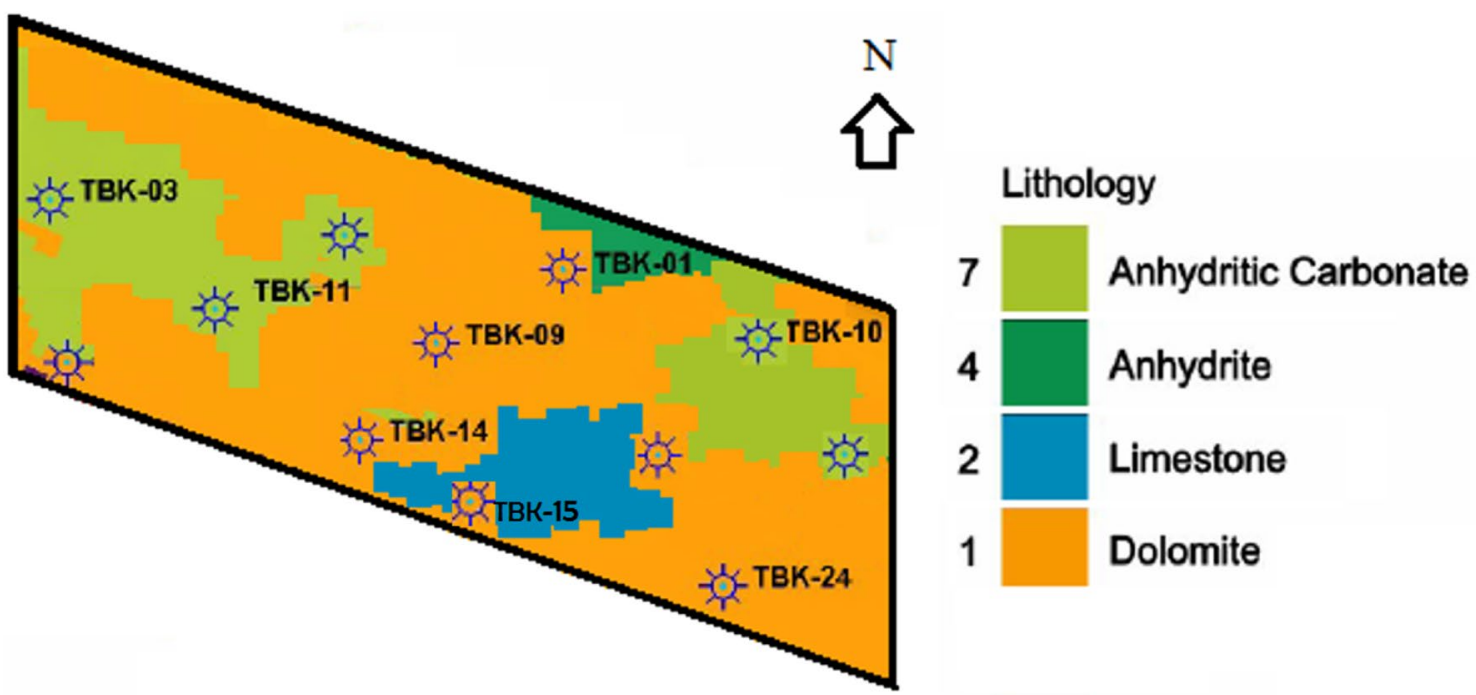

Fig. 5 Two-dimensional facies model for the Kangan Formation in the Tabanak hydrocarbon reservoir study area

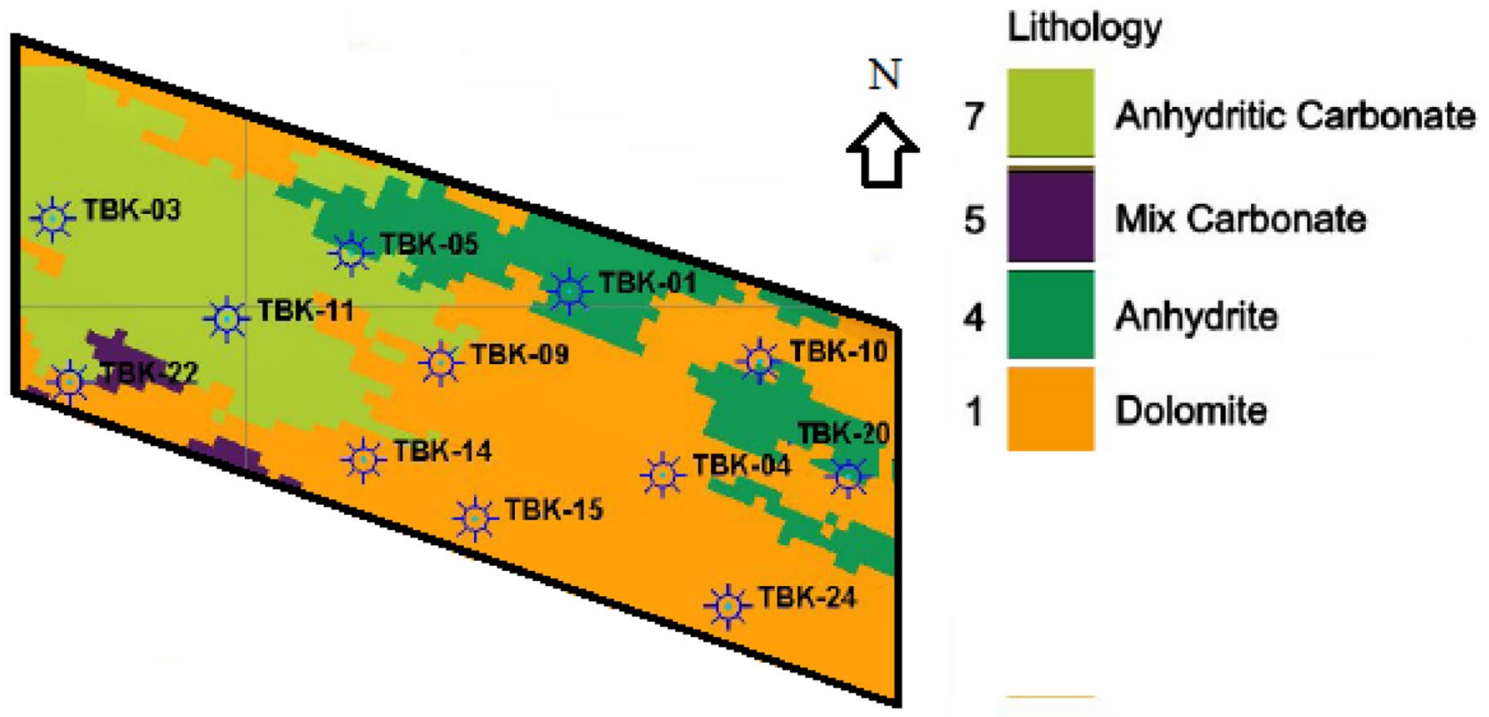

Fig. 6 Two-dimensional facies model for the Dalan Formation in the Tabanak hydrocarbon reservoir study area

\section{Modeling the surface fractures developed to the depth}

In this study's scope, each of the eight well is located on the carbonate lithology and consists of dolomite and limestone formations, mainly hydrocarbon-producing formations such as Dalan Formations and Dehram Group. It is also carbonate, so a model of surface fractures can be developed for this area in depth. For them, this pattern of fracture distribution can be modeled. The following steps are followed for this modeling:
1) Surface fractures distribution mapping (This map was prepared and compiled by combining fracture data from satellite imagery, facies models, and land surveys.)

2) Digitizing the surface fracture image (Using the image processing techniques in MATLAB R2019 software, the image was converted to the 0 and 1 binary format. All pixels larger than 0.5 were converted to 1 , and all pixels smaller than 0.5 were converted to zero.)

3) Preparing the Excel sheet files includes digital fractures. 
4) Determining the radius of each wells' impact using the Normal Kriging Analysis and SGeMS v2.0 software. (The impact radius for each well was determined.)

5) Fracture density estimation results converting to binary format $(0,1)$. (The fracture density values between 0.2 and $1.4 \mathrm{~m}^{2} / \mathrm{m}^{3}$ were converted to 0 and 1 ; especially the fracture density model cells between from 0.2 to $0.9 \mathrm{~m}^{2} /$ $\mathrm{m}^{3}$ were converted to 0 and fracture density model cells from 0.9 to $1.4 \mathrm{~m}^{2} / \mathrm{m}^{3}$ were converted to 1 .)

6) Combining the three categories of information (1. The surface fracture cells were converted to binary ( 0 and 1) 2. Estimated cells around each well according to the density of intracellular wellbore fractures and 3. Generalized cells to the impact wells radius.)
For each cell in the model without fracture data, the fracture property is developed. For each cell, the fracture information derived from the network estimation and generalization based on the impact radius is combined with the surface fracture data.

7) Converting the results to the intervals between 0 and 1 .

8) And finally, using the SGeMS v2.0 software, the surface fractures that developed to the depth model are represented as a three-dimensional model (Fig. 7).

As a sample in Fig. 8a, a two-dimensional fracturing model cross-sectioned on a three-dimensional surface fracture model developed to the depth was observed for $2350 \mathrm{~m}$. As shown in the given model, the fractures between wells

Fig. 7 Three-dimensional model of surface fractures that developed to the depth, Tabnak gas field
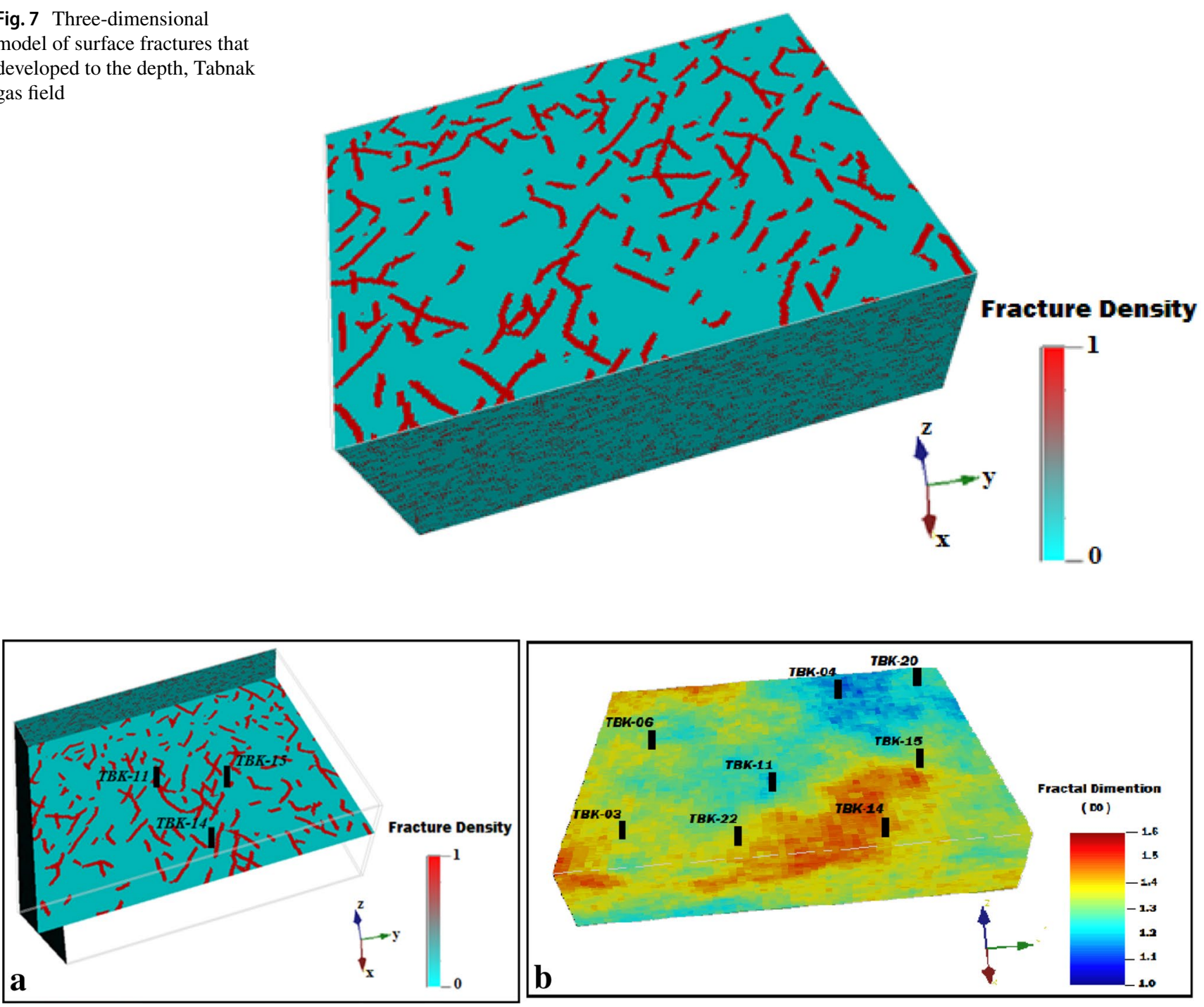

Fig. 8 a two-dimensional cross-sectional model of the three-dimensional model of surface fractures that developed to the depth of $2350 \mathrm{~m}$ on the study area, Tabnak gas field. b 3D fractal dimension model Tabnak gas field 
11,14 , and 15 are more focused and denser than other study areas.

These results have similarities with the fractal dimension model (Sarkheil et al. 2013) (Fig. 8b) and the results of mud loss and well test analysis.

\section{Conclusion}

This study performs a case study (a confined region in the back limb of Tabnak hydrocarbon reservoir). According to the study of structural studies done on the central Zagros area, it is possible to consider the bending-sliding type of flexural folding mechanism as most anticlines in this region. According to the stress distribution pattern and the type of fracture, issues from the tension on the floor and lower layers of the fold will be similar. Furthermore, it can be seen in the results of the two-dimensional model for the Kangan Formation, between wells 14 and 15, which are made of limestone and no shale, clay, and anhydrite, so that in the components of this region, there are no filled fracture materials. So, it can be a profitable area for open fractures and consequently, have a high potential for hydrocarbon or water production. The two-dimensional model of the Dalan Formation shows the dolomite and carbonate anhydrite components at a depth of $2750 \mathrm{~m}$.

Also, due to the recognition of the lithology of geological formations occurring on the earth's surface and the deep structures with the ability to produce hydrocarbons, we can model the surface using this research fractures' proposed algorithm developed to the depth.

So, referring to this pattern, in terms of opinion, is more appropriate. In addition, a cross-sectional view of the surface fractures developed to the depth distribution model, for the depth of $2350 \mathrm{~m}$, is possible to determine the distribution of fractures adjacent to wells 11,14 , and 15 . So, these distributions were profitable and in the wells' vicinity, affecting development plans and reservoir management strategy.

\section{Declaration}

Conflict of interest The authors declare that they have no known competing financial interests or personal relationships that could have appeared to influence the work reported in this paper.

Funding The authors would like to appreciate the comprehensive support provided by (ICOFC).

Open Access This article is licensed under a Creative Commons Attribution 4.0 International License, which permits use, sharing, adaptation, distribution and reproduction in any medium or format, as long as you give appropriate credit to the original author(s) and the source, provide a link to the Creative Commons licence, and indicate if changes were made. The images or other third party material in this article are included in the article's Creative Commons licence, unless indicated otherwise in a credit line to the material. If material is not included in the article's Creative Commons licence and your intended use is not permitted by statutory regulation or exceeds the permitted use, you will need to obtain permission directly from the copyright holder. To view a copy of this licence, visit http://creativecommons.org/licenses/by/4.0/.

\section{References}

Alavi M (1994) Tectonics of Iran's zagros orogenic belt: new data and interpretations. Tectonophysics 229:211-238

Alavi M (2007) Structures of the zagros fold-thrust belt in Iran. Am J Sci 307:1064-1095

Al-Rubaye A, Al-Yaseri A, Ali M, Ben Mahmud H (2021) Characterization and analysis of naturally fractured gas reservoirs based on stimulated reservoir volume and petro-physical parameters. J Petrol Explor Prod Technol 11:639-649. https://doi.org/10.1007/ s13202-020-01081-2

Barton CC, Larsen E (1985) Fractal geometry of two-dimensional fracture networks at Yucca Mountain, south-west Nevada. Stephenson $\mathrm{O}$ (ed) Proceedings of the international symposium on fundamentals of rock joints. Bjorkliden, Sweden, pp 77-84.

Berberian M, King GCP (1981) Towards a paleogeography and tectonic evolution of Iran. Can J Earth Sci 18(2):210-265

De Vera J, Gines J, Oehlers M, McClay K, Doski J (2009) Structure of the Zagros fold and thrust belt in the Kurdistan Region, northern Iraq. Trab Geol 29:239-243

Eahsanul Haque AKM, Aminul Islam M, Shalaby MR, Sadeque J (2018) Integrated 3D facies modeling of the Mangahewa formation, Maui gas field, Taranaki basin, New Zealand. J Petrol Explor Prod Technol 8(4):1017-1049

Everts HJ, Fakhari M, Verrall P (1977) The geology of the Surmeh and surrounding structures, fars north area. Iran Oil Op Co Geol Explor Division Rep 1251:68

Jamison WR (1987) Geometric analysis of fold development in overthrust terranes. J Struct Geol 9:207-219

Ouenes A, Zellou A, Basinski PM, Head CF (1998) Practical use of neural networks in tight gas fractured reservoirs: application to the San Juan Basin: Sof petroleum engineers rocky mountain regional/low permeability reservoirs symposium and exhibition. Denver, SPE Paper, p 39965

Sarkheil H, Hassani H, Alinia F (2009a) The fracture network modeling in naturally fractured reservoirs using artificial neural network based on image loges and core measurements. Aust J Basic Appl Sci 3(4):3297-3306

Sarkheil H, Hassani H, Alinia F, Enayati AA, Motamedi H (2009b) A forecasting system of reservoir fractures based on artificial neural network and borehole images information-exemplified by reservoir fractures in Tabnak field, Fars Iran. Int Multidiscip Sci GeoConf Expo Sgem 1:563-570

Sarkheil H, Hassani H, Alinia F, Enayati A, Nikandish A (2010) Fracture analysis in Tabnak hydrocarbon field of Iran by using fractal geometry and multi-fractal analysis. Arab J Geosci 5(4):579-586

Sarkheil H, Hassani H, Alinia F (2013) Fracture Distribution Modeling using Fractal and Multi Fractal-Neural Network Analysis in Tabnak Hydrocarbon Field, Fars. Iran Arab J Geosci 6(3):945-956

Sarkheil H, Rahbari Sh, Rayegani B (2020) Conversion based fuzzy fractal dimension integrating self-similarity and porosity, via DFS and FIS (Mamdani and Sugeno systems). Chaos Soliton Frac 140:110183. https://doi.org/10.1016/j.chaos.2020.110183

Sepehr M, Cosgrove J, Moieni M (2006) The impact of cover rock rheology on the style of folding in the Zagros fold-thrust belt. Tectonophysics 427:265-281. https://doi.org/10.1016/j.tecto.2006.05.021

Suppe J (1983) Geometry and kinematics of fault-bend folding. Am J Sci 283:684-721 
Suppe J, Medwedeff DA (1990) Geometry and kinematics of fault-propagation folding. Eclogae Geol Helv 83:409-454

Suppe J, Connors CD, Zhang Y (2004) Shear fault-bend folding, in K. R. McClay, ed., Thrust tectonics and hydrocarbon systems. AAPG Mem 82:303-323
Wallace WK, Homza TX (2004) Detachment folds versus fault-propagation folds and their truncation by thrust faults, in thrust tectonics and hydrocarbon systems (Ed. by K.R. McClay). AAPG Mem $82: 324-355$ 